\title{
Hurtos de colmenas: Apuntes históricos
}

\section{Theft of hives: Historical notes}

\author{
Pedro ORTEGO GIL \\ Catedrático de Historia del Derecho \\ Universidad de Santiago de Compostela \\ pedro.ortego@usc.es
}

Recibido: 18 de noviembre de 2014

Aceptado: 8 de enero de 2015

\begin{abstract}
RESUMEN
La producción apícola ha acompañado al ser humano desde la Antigüedad. Las colmenas y los productos de las abejas fueron bienes codiciados. Sus modos de explotación permitieron que fueran objeto de hurtos. Se trata de una delincuencia preferentemente vecinal. Desde antiguo estos delitos fueron gravemente penados, aunque con el transcurso de los siglos tal severidad se fue moderando.
\end{abstract}

PALABRAS CLAVE: Hurtos, Penas, Colmenas.

\begin{abstract}
Beekeeping has accompanied humans since Antiquity. Hives and bee products were coveted goods. Their modes of operation allowed them to be the subject of theft. It is delinquency of a mostly neighborly nature. Since ancient times these crimes were severely punished, however, over the centuries, this severity was progressively moderated.
\end{abstract}

KEYWORDS: Thefts, Punishment, Hives.

\section{RÉSUMÉ}

L'apiculture a accompagné l'être humain depuis l'Antiquité. Les ruches et les produits des abeilles furent des biens convoités. Leurs modes d'exploitation en firent l'objet de larcins. Il s'agit d'une délinquance avant tout de voisinage. Depuis les temps anciens ces délits furent lourdement punis ; cependant, au cours des siècles, cette sévérité s'est tempérée.

MOTS CLÉ : Larcins, Peines, Ruches.

En la actualidad no resulta difícil encontrar noticias sobre la sustracción de colmenas. En Andalucía los ladrones han dado al traste con una investigación de seis años de la Universidad de Córdoba sobre selección de abejas contra la varroa destructor, en Galicia los apicultores están alarmados ante el incremento de este tipo de 
robos, en otros lugares del centro peninsular se valora en más de mil euros cada colmena que los ladrones se han llevado. No es una conducta delictiva nueva, antes al contrario parece que ha acompañado al ser humano a lo largo de su historia.

La actividad de las abejas ha servido para polinizar y permitir que los árboles dieran el fruto necesario, para alimentar, para alumbrar y realizar ofrendas religiosas, e incluso para elaborar bebidas espirituosas como el aloja o vino de miel ${ }^{1}$. Ser dueño de una colmena conllevaba una pequeña riqueza y no pocos riesgos. Desde siempre el hurto de las colmenas, es decir, de abejas, miel y cera fue considerado un delito gravísimo y, por algunos, también atroz ${ }^{2}$. Calificación que derivaba, al menos, de las penas impuestas para su castigo, aunque no hubiera proporcionalidad legal con otros delitos $^{3}$. Quizá por esta desproporción y las circunstancias o necesidades de quienes los cometieron, los jueces no parece que se mostraran muy propicios a imponer las penas ordinarias, lo que dio lugar a que los autores que escribieron sobre apicultura denunciaran, implícitamente, que no se cumplía con el rigor legal ${ }^{4}$. Veremos, sin embargo, que los juzgadores diferenciarán entre el hurto del todo (colmena) y el que se comete sobre las partes (abejas o panales con su miel y cera).

\footnotetext{
${ }^{1}$ Acerca de las obras clásicas sobre estos temas, Braulio Antón Ramírez, Diccionario de bibliografía agronómica y toda clase de escritos relacionados con la agricultura, Madrid, 1865.

${ }^{2}$ «Los incendios, y hurtos, que se executan en los colmenares, están comprehendidos en la clase de delitos atroces, y por eso las leyes que proporcionan la pena con la culpa, las han establecido severísimas, contra los que cometen semejantes incendios, y robos. Lo cierto es, que los daños, que de semejantes delitos recibe la república, son crecidos; y que si los castigos se expresaran según los prescriben las santas y justas leyes de estos Reynos, serían pocos los atrevidos, y muchos los escarmentados. Algunos se arrojan a cometer estas maldades, no porque ignoran la gravedad del delito, sino porque no saben lo severo de la pena que les corresponde y tienen impuesta. Esta especie de gentes desprecia sin temor de la Suprema Magestad los castigos que en el fuero de la alma corresponden por Ley Divina a los malhechores y facinerosos, y suelen acobardarse y contenerse en sus iniquidades orgullosas a vista de las penas corporales, y visibles que executa en los malos la justicia de la tierra», según Diego de Torres Villarroel, Arte nuevo de aumentar colmenas. Reglas seguras para governar abejas, y para coger con abundancia la miel, y la cera, según las nuevas observaciones, y práctica de F. Moreno. Lleva al fin dos capitulos sobre el derecho de dominio a los enxambres remontados, y sobre las penas en que incurren los..., Madrid, 1761, pp. 354-355.

${ }^{3}$ Así lo puso de manifiesto Manuel de Lardizábal, Discurso sobre las penas, contrahido a las leyes criminales de España, Madrid, 1782, p. 50, al resaltar que: «No es menos extraña la ley de los antiguos saxones y burgundiones, que castigaba con la pena capital el hurto de un caballo, de una colmena de abejas, o de un buey, y con multa pecuniaria la muerte de un hombre». El texto era claro: "Qui nobilem occiderit MCCCCXL solidis componat... Qui alvearium apum infra septa alterius furaverit, capite puniatur». Cito por Ferdinad Walter, Corpus Iuris Gemanici antiqui, Berlín, 1824, tomo I, tit. Vi, De furtis, p. 386. ${ }^{4}$ «Siempre han sido mirados como atroces y castigados como tales los delitos de robos de colmenas e incendios de colmenares, imponiéndoles las leyes penas corporales gravísimas, que aunque se han mitigado y ya no están en uso algunas de ellas, no por eso han disminuido la gravedad de tales delitos; y para que se conozca o tenga presente esta por la enormidad de las penas que han tenido y tienen impuestas por las leyes, y en vista de ellas se abstengan de cometerlos los que teman más el castigo de los hombres que la ofensa y castigo de Dios, a quien nada se le oculta», según Pedro Abarca Castellano, Manual de colmeneros, o compendio de los que debe saber y método práctico, Madrid, 1835, pp. 280-281.
} 
Desde la perspectiva canónica no se puede olvidar que el hurto colmenas atentaba contra el Decálogo ${ }^{5}$. Incluso se aludirá a que solo Dios protege las colmenas, que producen además la cera para sus ofrendas ${ }^{6}$.

El interés jurídico por estos pequeños insectos aparece en el Derecho romano, que trató de resolver supuestos referidos a la propiedad de tales invertebrados. En D. 41, 1,5, 2-4, y 47,2,26 encontramos esta preocupación por proteger al poseedor o al propietario de las abejas y resolver los litigios que pudieran surgir por su volatilidad y aprehensión.

En Liber Iudiciorum 8,6,3 se plasma el castigo al hurtador de abejas: «Si quis ingenuus in appiaria furti causa fuerit comprehensus, si nihil exinde abstulerit, propter hoc, quod ibidem comprehensus est, tres solidos solvat et L flagella suscipiat. Ceterum si abstulerit, novecuplum cogatur exsolvere et praedictum numerum flagellorum excipiat. Servus vero, si ingressus nihil abstulerit, C verberibus addicatur. Quod si abstulerit, sexcuplo reddere conpellatur; pro quo si dominus satisfacere noluerit, eum serviturum illi, qui damnum pertulit, tradat» ${ }^{7}$. Rodríguez Mourullo distinguió en esta ley, a mi juicio correctamente, dos supuestos diversos de acuerdo con el iter criminis: el conato en los incisos primero y tercero, y el hecho consumado en el segundo y en el cuarto, de ahí la su diferente tratamiento y penalidad ${ }^{8}$. De dicho cuerpo legal pasaría a igual ley del Fuero Juzgo9. Téngase también presente la ley primera del mismo título y libro, sobre el quebrantamiento de la señal de quien se hubiere apropiado de un enjambre, es decir de quien dañara o de otro modo cambiara el signo de propiedad del vaso o colmena en que estuvieran recogidas las abejas. Veremos como en textos posteriores se conserva la pena pecuniaria, con variantes, mientras que la fustigación

\footnotetext{
${ }^{5}$ Martín de Azpilcueta, Manual de confessores y penitentes, Valladolid, 1570, p. 237, sobre el mandamiento de no hurtar: «Lo mesmo es del que tomó o mató, animales acostumbrados a tornar a casa: como son las avejas, pavones... Las avejas empero, o enxambres, antes que se pongan en las colmenas y otras aves, que alguno toma en árboles agenos, son de aquel que las toma. Y no comete hurto, aunque las tome en lo ageno, antes que el dueño le vede la entrada en su heredad, o que suba en su árbol, ni aunque las tome después. Puesto que en este caso le queda obligado por la injuria».

${ }^{6}$ Ao que desfai unha abelleira, Deus o condena; Deus garde as miñas abelleiras de quen lapa a mel; o, Deus non mande á miña abelleira, abellón que mel non quera, Luis Vicente López Méndez Esperante, «La abeja en la paremiología», en Boletín de la Real Academia Gallega, 305-308, 1955, pp. 107-130.

${ }^{7}$ Cito por Karl Zeumer, Leges Nationum Germanicarum. Tomo I. Leges Visigothorum. Monumenta Germaniae Historica, Hannover/Leipzig, 1902.

${ }^{8}$ Gonzalo Rodríguez Mourullo, «La distinción hurto-robo en el Derecho histórico español», en A.H.D.E., XXXII, 1962, pp. 25-111, la referencia en p. 51.

${ }^{9}$ En la versión romance: «Si algún ome libre entra en el logar de las abeias por las furtar, si no furtare ende nada, solamientre por que lo fallaraon hy peche III sueldos, e reciba L azotes. E si ende alguna cosa tomare, péchelo en IX duplos, e demás reciba los azotes de suso dichos. E si fuere siervo, e non levare ende nada del abeiero, reciba $\mathrm{C}$ azotes. E si algo ende levare, reciba $\mathrm{C}$ azotes, e péchelo en VI duplos. E si el sennor non quisiere fazer emienda por él, dé el siervo por emieda». Cito por Fuero Juzgo en latín y castellano, cotejado con los más antiguos y preciosos códices por la Real Academia Española, Madrid, 1815.
} 
no siempre se mantendrá en los cuerpos normativos ulteriores, como tampoco la discriminación por el status libertatis, sobre la que guardan silencio la mayor parte de tales textos.

En nuestra Edad Media, la regulación sobre esta materia deja de tener por sede exclusiva la ley para formar parte del ordenamiento jurídico local. Es probable que hasta la redacción de los fueros extensos se mantuviera vigente el contenido del Liber Iudiciorum sobre este hurto específico, y de ahí la laguna acerca de su regulación en los primeros textos forales. A partir de la recepción del Ius commune encontramos referencias particulares a los hurtos de colmenas en los fueros en los que es mayor su influencia, sin mención a la distinción que plasmó el cuerpo visigodo. Los litigios que surgen sobre la posesión y la sustracción de abejeras se producen habitualmente y en su mayoría entre vecinos, por lo cual parece lógico el interés de los textos forales por su ordenación. Entre los fueros que regulan el hurto de colmena, o de abejas ajenas en yermo o despoblado, así como la fijación de los medios de prueba por equiparación con otros delitos, figura el de $\mathrm{Cuenca}^{10}$ y por su influencia y con una redacción semejante, los de Zorita de los Canes $^{11}$, Iznatoraf, Andújar ${ }^{12}$, Úbeda, Alca-

\footnotetext{
${ }^{10}$ En el cap. XLI de la redacción sistemática : «Si quis alueolum cum apibus fregerit, aut dampnificauerit, pectet unum aureum. Si eum furatus fuerit, pectet ut latro, aut saluet se sicut de furto. Qui apes alienas siue in heremo siue in populato acceperit, aut furatus fuerit, pectet eas sicut dictum est. Si quis alueolare alienum uiolaverit, pectet sicut pro domo uiolata, uel saluet se, si probari non potuerit, tanquam pro uiolatione domi similiter»; y en su versión romanceada: «... i si alguno quebrantare colmena con abejas o la dannare, peche vn mr. i si la furtare pechela commo ladrón, o saluese commo de furto; i quien abejas ajenas en yermo o en poblado tomare o las furtare peche commo dicho [es]; i quien quebrantare colmenar ajeno, peche commo por casa quebrantada i saluese commo por casa quebrantada, si prouar non lo pudiere». Cito la edición de Rafael de Ureña y Smenjaud, El fuero de Cuenca (formas primitiva y sistemática: texto latino, texto castellano y adaptación del fuero de Iznatoraf), Madrid, 1935, pp. 786-787. Manuel Riú, «Agricultura y ganadería en el Fuero de Cuenca», en Estudios en memoria del profesor D. Salvador de Moxó, II, Madrid, 1982, pp. 269-386, donde destaca que «a la protección de las abejas y colmenas se refieren unas pocas líneas, suficientes para advertirnos del valor de la miel como condimento». Sobre estos preceptos, Francisco J. Gas, «Régimen jurídico del enjambre», en Revista Jurídica de Cataluña, 2, 1952, pp. 120-128; y, Gema Polo Toribio, «Abejas, enjambre, colmena. Evolución histórico-jurídica a la luz del Fuero de Cuenca», en Armando José Torrent Ruiz (coord.), Actas del II Congreso Internacional y V Iberoamericano de Derecho Romano: Los derechos reales, Madrid, 2001, pp. 211-231.

${ }^{11}$ «807... Decabo, si alguna colmena con abeias alguno quebrantare o dannare, peche i marauedí. Si por auentura la íurtare, péchela assi como ladrón, o saluese assi como por furto. Aquel que abeias agenas en yermo, o en poblado las tomare, o las furtare, peche la segund dicho es. Et tod aquel que colmenar ageno forçare, peche assi como por casa forçada, o saluese, si prouar no lo pudiere, assi como por quebrantamiento de casa...». Utilizo la edición de Rafael de Ureña y Smenjaud, El Fuero de Zorita de los Canes según el Códice 247 de la Biblioteca Nacional (siglo XIII. Al XIV) y sus relaciones con el Fuero latino de Cuenca y el romanceado de Alcázar, Madrid, 1911, pp. 355-356.

${ }^{12}$ Título DCXXVII: «Otrosy sy alguno colmena con avejas quebrantare, peche I maravedí; e si la furatre, peche como ladrón o salvese como de furto. Aun aquel que avejas ajenas tomare, syquier en yermo syquier en poblado, o las furtare, péchelas como dicho es. E sy alguno colmena ajena quebrantare, peche como por quebrantamiento de casa; e sy provar non le pudieren, salvese como sy quebrantase casa»,
} 
raz, Alarcón, Sabiote ${ }^{13}$ o Plasencia ${ }^{14}$. No se conforman con regular la posesión de los enjambres (silvestres) sino también el hurto y el daño en las colmenas o en las abejas, tanto en yermo como en poblado. Aunque los productos apícolas, miel y cera, no se mencionen de modo expreso, es obvio que hay que incluirlos en la medida en que se habla de quebrantar o dañar colmena como acción diferenciada de hurtar. Las circunstancias del momento en que fueron redactados estos textos exigía determinar la prueba para demostrar la posesión o, en su caso, la perpetración del hurto, cuya delimitación tratándose del aprovechamiento de las abejas era en ocasiones muy débil. La concreción de la prueba y del castigo delata la importancia dada a las abejas, en cuanto equiparan el daño con fuerza en el colmenar al quebrantamiento de casa. El fuero de Teruel presenta una regulación similar, como los anteriores con vista en el Derecho romano, aunque la versión romanceada permite apreciar la sistematización normativa sobre hurto y daño de colmena, de enjambre y de colmenar:

739. Del que piçiare colmena agena. De[cabo], si alguno colmena agena piçi[a]re con abe[i]as o dannare et a él prouado'l fuere, peche [V] sueldos; si non, iure solo e sea credido. Mas s[i la colme]na fuere furtada et a él prouado'l [fuere, peche] la assí como [ladrón o] salue se as[sí como] de furto.

740. Del que abeias furtare. Otrosí, qual quiere que abeias age[nas] en yermo o en poblado prisiere o furtare et a él prouado'l fuere, peche las assí [como] ladrón o salue se ass[í co]mo de furto.

741. Del que colmenar ageno quebrantare. Decabo, si alguno colmenar ageno quebrantare et a él prouado'l fuere, peche CCC sueldos o salue se con XII uezinos e sea credido; mas ni non cunpliere, peche assí como de suso es auant dicho ${ }^{15}$.

La influencia del Ius commune se reflejará no solo en los textos forales extensos sino, por supuesto, en la legislación real que atiende, más que al castigo del hurto, a cuanto afectaba a la propiedad y posesión de los enjambres. Según el tenor de Fuero

Fuero de Andújar. Estudio y edición, edición de Emiliano González Díez y Félix Martínez Llorente, Jaén, 2006, pp. 227-228.

${ }^{13}$ «827... Si alguno uaso con abejas quebrantare o dannare, peche un marauedí, mas si’l furtare, peche'l commo ladrón o sáluese commo de furto. Et aquél que abejas ajenas tomare, si quier en yermo o si quier en poblado o las furtare péchelas commo dicho es. Et sj alguno colmenar ageno quebrantare, peche assi commo por quebrantamjento de casa, et si prouar non gelo pudieren, sáluese commo por quebrantamiento de casa...», en Pedro A. Porras Arboledas, «El fuero de Sabiote», en Cuadernos de Historia del Derecho, I, 1994, pp. 243-441.

${ }^{14}$ María Josefa Postigo Aldeamil, «El Fuero de Plasencia», en Revista de Filología Románica, III, 1985, pp. 169-222. El título de «enxanbres e corchetes» (666) disponía por lo que aquí interesa que: «Si alguno baso con abeias quebrantare o dannare, peche I moravedí. Aquel, otrosí, que abeias agenas, en yermo o en poblado, prisiere o furtare, péchelas como dicho es. Si alguno colmenar ageno quebrantare a fuerça peche commo por casa forçada o salvese como por casa quebrantada, si provar non pudiere».

${ }^{15}$ Max Gorosch, El fuero de Teruel según los manuscritos 1-4 de la Sociedad Económica Turolense de Amigos del País y 802 de la Biblioteca Nacional, Estocolmo, 1950, pp. 376-378. El texto latino en El fuero de Teruel (edición crítica, introducción y traducción de José Castañé Llinás), Teruel, 1989, pp. 703-705. 
Real 3,4,17: «Maguer abejas que enjambren suben en árbol de alguno; si otri las tomare, e las encerrare ante que el dueño del árbol las pueda haber, maguer que el árbol faga enjambre; pero el señor del árbol pueda defender a todo home que no entre en lo suyo ante que las abejas sean presas y encerradas; fueras el señor de cuya colmena salieron las abejas viniendo en pos ellas; ca este mientra va tras sus abejas por las cobrar, no pierde el derecho, que en ellas habíe... Mandamos que se las haya quien las tomare, si el señor cuyas fueren no va en pos ellas» ${ }^{16}$. En Partidas hay que acudir a $3,28,22$, que al abordar las cosas en que ome puede aver señorio determina cómo gana el hombre el señorío de las abejas y enjambres, plasmando la tradición romana acerca de la propiedad de las abejas, aunque esta ley no entra a regular su sustracción. En modo alguno cabría insertar estos hurtos en P. 7,14,19, que es la ley dedicada a los abigeos.

La producción de las abejas debió de incrementarse a medida que se conquistaban territorios hacia la meseta sur. Su multiplicación debió ser pareja al incremento de hurtos y daños en las posadas de colmenas. Esta situación obligó a sus propietarios a organizarse para defender la producción apícola que les pertenecía. Cabe recordar que en la formación de la Hermandad de Toledo, Talavera y Ciudad Real participaron los colmeneros que tuvieran más de treinta -número que varió- colmenas o, al menos, una posada de colmenas ${ }^{17}$.

Además de la legislación regia y foral, diferentes ordenanzas municipales recogieron disposiciones específicas sobre colmenas y colmeneros, aunque de ordinario en ellas no se hace mención a los delitos cometidos sobre aquellas, ni por extensión a su castigo. Las más famosas fueron las Ordenanzas de colmenas y sus majadas de Sevilla, cuyo contenido está destinado al aprovechamiento y regulación de las explotaciones apícolas, como también a la jurisdicción de los alcaldes colmeneros, que era civil y no criminal ${ }^{18}$. Estas ordenanzas sevillanas de Alfonso XI, ratificadas por Enrique II en 1367 y Enrique IV en 1437, establecieron que «si alguno encubriere colmenas hurtadas en su majada, que se pare [sic] a la pena de la justicia del Rey. Y si se escapare por pecho, o por ruego, no sea en el común de los colmeneros. E si el su

\footnotetext{
${ }^{16}$ Vid. también Espéculo 5,8,7.

${ }^{17}$ Además de las obras generales sobre la Hermandad, José María Sánchez Benito, «La Hermandad de los Montes de Toledo entre los siglos XIV y XV», en Espacio, Tiempo y Forma. Historia Medieval, 18 (2005), pp. 209-230, y «Hermandades y delincuencia rural entre el Tajo y Sierra Morena (siglos XIIIXV)», en Clio \& Crimen, 3 (2006), pp. 134-166.

${ }^{18}$ Gabriel Alonso de Herrera, Agricultura general, que trata de la labranza del campo y sus particularidades, Madrid, 1777, pp. 440-447: «Síguense las leyes y ordenanzas de las Colmenas, que fueron sacadas de la Recopilación de las Ordenanzas hechas para la buena gobernación de la Ciudad de Sevilla, y de su tierra». De 8 de marzo de 1254. Son básicamente disposiciones de buen gobierno y no hay referencia al hurto de colmenas. Sobre su aprovechamiento en esta tierra, María Antonia Carmona Ruiz, «La apicultura sevillana a fines de la Edad Media», en Anuario de Estudios Medievales, 30/1 (2000), pp. 387-422, quien resalta la obligación de herrar las colmenas con la señal del propietario, hurtos o pérdidas.
} 
hombre lo encubriese, y el señor no lo supiere, que el home que se pare a la justicia; e aquel home si escapare, no lo reciba ningún colmenero tan solamente por la fama; y si lo recibiere, que peche doce maravedís a los alcaldes de los colmeneros, e que lo eche de sí» ${ }^{19}$. En ellas se contienen, además, numerosos preceptos sobre los incendios que afectaban a las colmenas, de manera que «qualquiera persona que pusiere fuego, y se probare que lo fizo maliciosamente, sea castigado criminalmente conforme a las leyes del Reyno», según se determinó en 1514. Por tanto, se establece una delimitación jurisdiccional, puesto que los asuntos civiles corresponden a los alcaldes colmeneros mientras que las justicias ordinarias se encargarían de la represión criminal. Esta sería la justificación del silencio de las ordenanzas municipales en punto a la punición de estos hurtos. Lo que, sin embargo, no sucedió en todos los casos.

En las Ordenanzas de 1504 para Huelva y el condado de Niebla se estableció que «ninguno vaya a colmenar ageno a coger las enjambres que de él se salieren que estuvieren posadas cerca del tal colmenar, porque el que tales enjambres tuviere pedirlas han por hurto, e pagarlas han con las setenas, salvo si las tales enjambres se fueren lejos de ende y su dueño no las viese ni siguiese tras ellas, que entonces será de quien las hallare» (405). Además se completaba este precepto, al determinar que «ninguno hurte corchos de colmenar de otro ni témpanos ni corchas ni otras cobijaduras so pena de seiscientos maravedís para las obras, el tercio para el acusador y a su dueño, con el doblo, de lo que así tomare» $(406)^{20}$.

A estas ordenanzas se pueden añadir algunas posteriores como las de Plasencia o Jaén, entre otras muchas. Las de Plasencia de 1533 incluyen una justificación muy difundida sobre la importancia de las abejas:

«Necesidad de las colmenas. Hordenamos e mandamos e decimos, que por quanto las colmenas son mui provechosas e neçesarias, porque la cera se gasta en honra e servicio del culto divino e sacrificio del altar, e ansí mesmo, [se] aprovecha para los enterramientos de los difuntos e para servicio de los vivos. E la miel para medicinas y cosas necesarias para la vida humana.... ${ }^{21}$.

\footnotetext{
${ }^{19}$ Además, «si fulgines anduvieren por la sierra, o otros homes, a daño de los colmeneros, e por las jaras, y los alcaldes, e los cinco homes buenos quisieren ir en pos de ellos por prendellos, e por castigallos, que todos los colmeneros les fagan la costa que ficieren, fasta ocho días, si no hobiere del común que tomar». Más adelante se establece que «todo home que atoconare corchos alrededor de las majadas de los vecinos, o se los fallaren, que lo puedan prender sin caloña ninguna, e decillo a la justicia, e parese a la pena que el fuero y el derecho manda. E por el daño que reciben sus majadas del atoconar, que las colmenas que éste tal tuviere atoconadas, que sean del más cercano vecino donde se las fallaren faciendo aquel daño». Alonso de Herrera, Agricultura general, p. 443.

${ }^{20}$ Isabel Galán Parra, «Las Ordenanzas de 1504 para Huelva y el condado de Niebla», en Huelva en su Historia, 3, 1990, pp. 107-174.

${ }^{21}$ Gloria Lora Serrano, Ordenanzas municipales de la ciudad de Plasencia, Sevilla, 2005, p. 135. Vid. también, Patricio Hidalgo Nuchera y F. Padilla Alvarez, Las ordenanzas de colmeneros del concejo de Córdoba: (siglos XV-XVIII), Córdoba, 1998.
} 
La protección que dio la Santa Hermandad a los colmeneros y la regulación de la misma, de acuerdo con sus ordenanzas de 7 de julio de 1496, pasó a Nueva Recopilación $8,13,2$ y 3 , a propósito de considerarse caso de hermandad el hurto y quema de colmenas, identificándose los conceptos de hurto y robo, al tiempo que se estableció una punición agravada de conformidad al valor de lo sustraído -que se fija por tramos-y que podía llegar a la imposición de la pena capita ${ }^{22}$. De acuerdo con la redacción de la primera de las leyes citadas, entre los hechos y delitos de los que debían conocer sus jueces se dispone que «sea caso de Hermandad quemas de casas, y viñas, y mieses, y colmenares, haciéndose a sabiendas en yermo o en despoblado; y entiéndase ser yermo, o despoblado para en los casos de Hermandad el lugar descercado de treynta vezinos abaxo; entiéndase ser robo, y furto, aunque el dueño de los tales bienes no esté presente, y aunque aya resistencia, o no la aya $\rangle^{23}$. Texto que pasaría a Novísima Recopilación $12,35,2$, y en el que existe una diferencia notable con los textos forales: estos hablan de hurtos cometidos «en yermo o en poblado», mientras que la legislación recopilada se refiere a los perpetrados «en yermo o en despoblado». En cualquier caso, todos quienes se remitieron a esta ley advirtieron la dureza de sus penas ${ }^{24}$, de lo cual deducían la gravedad del delito cometido ${ }^{25}$. Una severidad legal que no sería exclusiva de Castilla. Severidad que en modo alguno redujo estos hurtos ${ }^{26}$.

\footnotetext{
${ }^{22}$ «Mandamos que los delinqüentes que uvieren robado, o hurtado en yermo, o en despoblado, sean punidos, i castigados en esta manera: que si el robo, o hurto fuere de valor de ciento i cincuenta maravedís, i dende abaxo, que sea desterrado, i le den pena de azotes, i pague más lo que así robó con el dos tanto a la parte; i con el quatro tanto para los gastos de la Hermandad; i si fuere de ciento i cincuenta maravedís arriba hasta quinientos maravedís, que le sean cortadas las orejas, i le den cien azotes; i si fuere de quinientos maravedís arriba hasta cinco mil maravedís, que le corten el pie, i que sea condenado a que nunca cavalgue en cavallo, ni en mula, so pena de muerte de saeta; i si el dicho robo fuere de cinco mil maravedís arriba, que muera por ello el tal malhechor muerte de saeta; pero en todos los otros casos de Hermandad, excepto en los contenidos en la lei antes desta, mandamos que los jueces de la Hermandad den a los malhechores la pena, o penas, que según la qualidad, o gravedad de los delitos ovieren merecido, o debrían merecer, según Derecho, i leyes de nuestros Reinos; con tanto que los que fueren condenados a pena de muerte, sufran, i les sea dada muerte de saeta». Cito por Recopilación de las leyes destos reynos hecha por mandado de la magestad catholica del Rey don Philipe segundo, Alcalá de Henares, 1569.

${ }^{23}$ El verbo robar en materia apícola tiene otro significado: "Escorchar es lo mismo que robar, o desnudar del todo la colmena". Jaime Gil, Perfecta y curiosa declaración de los provechos grandes, que dan las colmenas bien administradas, y alabanzas de las abejas, Zaragoza, 1621, Tratado 4, cap. 16, n. 4 y 6 (ff. 87v y 88v). Acerca de la delimitación conceptual entre ambos delitos, José Sánchez-Arcilla, «Robo y hurto en la ciudad de México a fines del siglo XVIII», en Cuadernos de Historia del Derecho, 8, 2001, pp. 43-110.

${ }^{24}$ Abarca Castellano, Manual de colmeneros, pp. 280-281: «Las penas impuestas a los que roban en yermo o despoblado por la ley 3, tít. 13, lib. 8 de la Recopilación (antigua) son de azotes, corte de orejas y pie, y muerte de saeta, según fuese el valor del hurto».

25 «Estas penas están declarando lo enorme del delito que cometen los que queman y roban colmenares; y aunque es verdad que la pena de mutilación de miembros hoy no está en uso, pero sí la de los cien azotes, siendo leve el daño, y creciendo a grave se impone la de doscientos azotes y galeras; observándose asimismo en este asunto lo dispuesto por los estatutos particulares de los pueblos, estando legíti-
} 
En tierras navarras, las Cortes de Tudela 1558 reconocieron que por no haber ley ni orden sobre las colmenas y abejeras se producían grandes inconvenientes, por la disminución y encarecimiento de la miel y de la cera $^{27}$. Para lo que nos interesa en estas páginas, se prohibía a cualquiera «que catare o escarzare, o robare, o maltratare vaso, o vasos de abejas agenas, o entrare en las abegeras para las catar, o escarzar, o hurtar contra la voluntad de su dueño, incurra por ello, si fuere persona vil, en pena de cien azotes; y si fuere hijo dalgo en pena de destierro de un año del Reino, y del daño que hiciere, y más en pena de cien libra. La tercera parte de la dicha pena pecuniaria para el acusador, y la otra tercera parte para el dueño, y la otra tercera parte para el juez que lo sentenciare». En las Cortes de Pamplona de 1632 se acordó «contra los ladrones de ganado menudo y de abejeras y colmenas», además de que los alcaldes ordinarios, aunque no tuvieran jurisdicción criminal, pudieran actuar contra ellos, asistidos de asesor, y en particular a los que «escarçaren o robaren o maltrataren bassos, abejeras o colmenas» imponerles doscientos azotes y cien libras conforme a la ley anterior ${ }^{28}$. Penas que acabarían por agravarse, aunque con separación estamental ${ }^{29}$.

En otros territorios la severidad penal aún era mayor. Antonio Planas advierte de la dureza en la punición del hurto de colmenas en Mallorca. En particular, resalta que el edicto de Carlos de Pomar de 25 de julio 1525 estableció que por el primer hurto el reo fuera expuesto en la picota durante tres horas, el segundo con dicha exposición y la amputación de las orejas y el tercero con la pena de muerte ${ }^{30}$. Con posterioridad, otros edictos

mamente aprobados, y aquello que por costumbre legítima se hubiere introducido, que en tales casos lo que por aquellos se ordena, y lo que por esta se dispone, es lo que se debe observar y cumplir», Torres Villarroel, Arte nuevo, pp. 358-359.

${ }^{26}$ Los colmeneros lorquinos redactaron unas ordenanzas para la guarda de colmenas, aprobadas por Real ejecutoria de 11 de mayo de 1561, cuya causa estaba en «evitar, e castigar los hurtos, e daños que tan a menudo se acostumbran hazer en esta ciudad, como a todos es notorio», en Ordenanzas de Lorca (introducción de Guy Lemeunier e índices de Miguel Rodríguez Llopis), Murcia, 1983, pp. 57-65. En ellas se plasman la intervención de los veedores o las restricciones impuestas a los forasteros.

${ }^{27}$ Regulación que encontramos en el título octavo del libro quinto, que es el dedicado a las colmenas y abejeras. A continuación siguen las disposiciones que afectan a la cera. Cito por Novísima Recopilación de las leyes de el Reino de Navarra hechas en sus Cortes generales desde el año 1512 hasta el de 1716 inclusive, Pamplona, 1735.

${ }^{28}$ Actas de las Cortes de Navarra (1530-1829), Pamplona, 1993, lib. II, pp. 221-222. Novísima Recopilación de las leyes de el Reino de Navarra 4,6, 4.

${ }^{29}$ Con mayor concreción se señalará que: «El que hurtare, o catare o escarzare vasos de abejas, o entrare en las abejeras con este objeto, por el primer hurto tenga de pena, si fuere persona vil 100 azotes, y si fuere fidalgo, destierro del Reino por un año y 100 libras y el daño; por el segundo hurto siendo persona vil 100 azotes y 8 años de galeras; y si fuere fidalgo 8 años de destierro del Reino; y por la tercera vez 6 años de gentilhombre de galeras o en Orán a su costa». José Yanguas y Miranda, Diccionario de los Fueros del Reino de Navarra, San Sebastián, 1828, p. 326. Él mismo aclaraba que: «Esta primer pena contra los hurtos de abejeras estaba ya impuesta en la ley del año $1533,1^{\text {a }}$ del lib 5 , tit. 8 ; y a ella se refiere la ley de que estamos hablando que es del año 1652».

${ }^{30}$ «[17] Més avant statuheix, proveheix, ordona y mana Se Spectable Senyoria que per quant en la present illa se ha molta disposició de tenir abeyes e conrar.se les mells e seres, que serie molt spedient 
lo castigaron con galeras perpetuas o muerte; y disposiciones ulteriores con la pena de correr la villa y cinco años de galeras aun cuando se hubiera hurtado una sola colmena ${ }^{31}$.

En la cercana isla de Ibiza también se dictaron disposiciones contra quienes hurtaran o rompieran las casas de las abejas, justificándolo en «la falta, que hi ha en la Illa de cera, mel, y lo que importa el custodir, y guardar la provisiò de las referidas cosas, pera lo qual es necessari imposar graves penas, contra los que ab poch temor de Deu N.Sr. y de la justicia temporal compren, y destruixen las casas de abellas, lo que de ordinari si experimenta en esta Illa». Ante la gravedad de la situación, agravación de la pena, ejecución inmediata de la misma e imposibilidad de entablar recursos, de modo que «qualsevol, que furtarà mel abellas, ò rompra casas de estas, que no sian suas, aquell, ò aquells, que tal cosa hauràn comesa, y perpetrada incuriràn en pena de tres añys de galeras, conforme los lladres de carn, la qual pena declarada per dit G[oberna]dor, ab juy de prohoms sia encontinent executada, sens admetrer recursos, ni appellaciòs, ni altres difugis ${ }^{32}$. Pasaje que ratifica la importancia que tenían las abejas en los lugares más dispares.

Unas disposiciones, legales o consuetudinarias, que debían de aplicarse en cada lugar con preferencia sobre el Derecho común, como afirmaba con meridiana claridad Torres Villarroel ${ }^{33}$.

per lo bé de la repúbliqua e singulars de aquella lo que segons informació verídica farien molts si ere obviat a la sinistra intenció de molts mals y perversos hòmens qui no dubten furtar e romper les cases de les dites abeyes, e sie per conseguent necessari que en açò sie debitament provehit. Per tant, mana lo dit spectable y noble senyor Lochtinent General que qualsevol persona qui en alguna part de la present illa furtarà o furtar serà alguna casa de abellas, o l.exam de aquelles, lo qual serà en loch ha hont algú tindrà o conrerà abeyes o mell obtes que de les dites cases o romprà o romper fara alguna de elles, per lo primer furt per poch que sia e per lo rompiment de dites cases sien postas en lo costell de la place mova e aquí stiguen a la publique vergonya per spay el menys de tres gores tot nus, e per lo segin furt e rompiment de les dites cases de abeyes stiguen aximatex en lo dit costell e.ls sien levadse les orelles, e per lo ters furt e rompiment de dites cases sien penjants per lo coll o.ls sia donade altre pena de mort sens alhuna gràcia e mercè», en El Derecho penal histórico de Mallorca (siglos XIII-XVIII), Palma de Mallorca, 2001, pp. 107 y 193-194.

${ }^{31}$ En el edicto del lugarteniente y capitán general Gaspar de Marrades de 30 de abril de 1549, el cap. XIII está dedicado a las abejas: «Més avant mane que per quant en la present illa ha molta dispositió de tenir abeyes de las quales se produexen les mels y ceras y de aquellas és inluminat lo cors sagrat de Jesuchrist. E com molts fills de perditió, poch tament nostre senyor Déu ni la real correctió, no dupten de traure les cases de les abellas, furtar y disispar aquellas, lo que és en gran deservey de nostre senyor Déu. Per tant Sa Spectable Senyoria mane y denuntia que qualsevol persona qui futrterà o romperà les cases de las abellas sens voluntad del senior, ni furterà bestiar de qualsevol manera sia, o grabes de forment, ordi y de altre gra, si de tal furt o rompiment de dites cases de abellas serà legítimament convensut, incorregue pena de condampnatió en las galeras de Sa Magestat de vida sua, resevant.se Sa Senyoria arbitre y facultat de condempnar tal ladre a mort natural si la qualitat del furt ho requerirá. E si lo dit ladre serà sclau incorregue la pena de correr la vila ab assots, sens perjury de statuts y ordinations altres per dit effecte fetes», Ibd., p. 205.

${ }^{32}$ Reales Ordinaciones de la isla y real fuerça de Iviza, Palma, 1751, libr. II, Causas criminales, p. 138.

${ }^{33}$ «Esto es lo que en asunto de pertenencia de abejas y de enxambres está decidido por Derecho, y esto es lo que deben observar los colmeneros, y los que no lo son, estando determinado lo contrario por estatutos municipales legítimamente aprobados, o por costumbre rectamente introducida, y tal que tenga 
Es preciso contrastar la teoría legal con la práctica delictiva y la judicial para acercarse a la realidad penal de este delito. Las posibilidades delictivas de este hurto van desde la extracción de los panales, esto es, el escarceo de la miel y la cera, o más raramente solo de las abejas, hasta el supuesto en que el ladrón se lleva la colmena, cortijo o vaso, es decir, lo que en las fórmulas contenidas en los autos judiciales se expresa como hurtos de «colmena, miel y cera». Por la documentación que he consultado creo que, a efectos punitivos y de compensación de daños, se distinguió entre el hurto de colmenas, como regularon los textos normativos, y el escarceo o sustracción de los panales, pudiendo ser este último completo -con el consiguiente daño para las abejas- o parcial. La diferencia de valor entre unos y otros hechos, así como el daño producido en los primeros repercutió indudablemente en su penalidad. En el caso de los enjambres pueden plantearse dudas sobre si el asunto en litigio era civil o criminal.

Mendoza ha puesto de manifiesto la frecuencia con que los hurtos de colmenas, cera y miel aparecen en la documentación de la Hermandad, pues el origen de esta institución se encuentra en la protección que buscaron los colmeneros de la meseta meridiona ${ }^{34}$. La ubicación de los colmenares -a distancia de las poblaciones-, sus métodos y épocas de aprovechamiento, los frutos que en ellos había y su fácil comercialización los convertían en bienes codiciados. Los autores de estos hurtos fueron colmeneros que actuaban contra sus colegas, criados colmeneros respecto de sus amos y personas necesitadas. Los colmeneros ladrones, de ordinario, vendían la cera y la miel o la trocaban por otros productos alimenticios. Como afirma el citado historiador, «el principal enemigo del propietario de una posada de colmenas era su propio asalariado, cuya actividad era difícil de controlar por la lejanía del amo», lo cual puede comprenderse, en parte, por la dura vida que llevaban estos individuos en el monte o en zonas muy apartadas de cualquier comunidad. Las excusas planteadas por los reos para evadirse del castigo eran los ataques de osos, con el consiguiente destrozo de los abejares, pero también «que la hanbre se lo hazía hacer», aun cuando el propio Mendoza excluye estos hurtos de la vinculación que pueda darse entre robos de alimentos y crisis de subsistencias, pues a pesar de que la miel era alimento de primer orden, no era el exclusivo objetivo de los ladrones de colmenas ${ }^{35}$. Sin obviar que los colmeneros, solos o en compañía de sus parientes, también se dedicaron a todo tipo de hurtos ${ }^{36}$.

todas las circunstancias que le den fuerza de ley; pues habiendo algo de esto, sin embargo de lo decidido por Derecho común, se ha de guardar y cumplir enteramente lo que el estatuto o costumbre resuelva», Arte nuevo, p. 354.

${ }^{34}$ Juan Miguel Mendoza Garrido, Delincuencia y represión en la Castilla bajomedieval: los territorios castellano-manchegos, Granada, 1999, pp. 299-301. Del mismo autor y con mención a hechos delictivos sobre colmenas con participación de mujeres, «Sobre la delincuencia femenina en Castilla a fines de la Edad Media», en Ricardo Córdoba de la Llave (coord), Mujer, marginación y violencia entre la Edad Media y los tiempos modernos, Córdoba, 2006, pp. 75-126.

${ }^{35}$ Mendoza, Delincuencia, p. 312.

${ }^{36}$ Mendoza, Delincuencia, p. 524, por ejemplo. 
Entre los castigos dictados por la Hermandad contra ladrones de colmenas que aporta Mendoza, figura la pena de muerte impuesta a un colmenero, a quien previamente se había sometido a tormento por haber robado las de su amo y haber confesado la comisión de innumerables robos ${ }^{37}$. En este caso puede plantearse que se valoró la incorregibilidad del reo, es decir su habitualidad, pues como apunta dicho historiador fue considerado ladrón; a lo que habría que agregar que la víctima era su propio amo y que añadió delito sobre delito. Esta pena puede presentarse como la excepción en la punición de los hurtos de colmenas, pues parece traer causa de otros hurtos más graves o le fue impuesta por el conjunto de ellos.

Mediado el siglo XVI tenemos noticia de que en La Rioja se produjo el robo de una colmena, cuya causa criminal acabó ante a los alcaldes del crimen de Valladolid. En ella se comprueba cómo las partes enfrentadas pertenecen a la misma vecindad. El afectado acusó a un convecino de Fuenmayor porque «con otros que le avían dado favor e ayuda, le avían hurtado e robado uno de los dichos vasos con las dichas abejas e myel y cera que podía valer todo ello como estaba tres ducados», por lo cual los autores habían incurrido en graves penas, al tiempo que reclamaba la restitución de la colmena o su justo valor. Tenemos en esta querella todos los elementos materiales típicos de estos hurtos: colmena, cera, miel y tasación. De por medio se encontraba la jurisdicción de los alcaldes de la Santa Hermandad, lo que motivó la presentación de un artículo de declinatoria. Al final, el acusado fue condenado por el alcalde de la Hermandad de Logroño en las costas, lo que ratificaron los alcaldes del crimen vallisoletanos ${ }^{38}$.

A finales del siglo XVI llegó a la Chancillería de Valladolid otra causa en apelación de la sentencia dictada por el alcalde mayor de Arenas de San Pedro contra un vecino de dicha villa, menor de edad, acusado de que en el mes de abril de 1591 había hurtado colmenas ${ }^{39}$. El proceso se inició cuando otro vecino de la villa compareció ante la justicia porque «avían urtado a vecinos de la dicha villa cantidad de colmenas en especial el dicho día segundo avían urtado una colmena a Luis de la Fuente de las que tenía en el valle...». Se procedió contra el acusado y se le hizo culpa, aunque el querellante se apartó y le perdonó porque la colmena fue restituida, pues aquél se arrepintió tras ser descubierto. No obstante, la causa continuó por interés de la vindicta pública, y no es el único supuesto que he encontrado. En el escrito de acusación se incidió, como exigía la legislación recopilada, en que la colmena se hallaba «en el campo yermo y despoblado». Además se alegó que el acusado había actuado con poco temor de Dios y de la justicia, contra la voluntad y sin el consentimiento del dueño, pues «avía tomado y urtado una colmena de las dichas colmenas del dicho Luis de la Fuente y avía sido allado con la dicha colmena que la avía traído envoçada

\footnotetext{
${ }^{37}$ Mendoza, Delincuencia, pp. 300-301, 476 y 498.

${ }^{38}$ Archivo de la Real Chancillería de Valladolid, Ejecutorias, 836/68.

${ }^{39}$ ARChV, Ejecutorias, 1.698/6.
} 
y a vistas para mudarla a otra parte para más ocultar la dicha colmena y encubrir el dicho delito, y como avía sido allado con el dicho urto avía vuelto la dicha colmena al dicho Luis de la Fuente y al sitio donde la avía urtado, y en lo ansí aver fecho avía cometido grave y atroz delito». Se solicitaba que el acusado fue declarado por autor y perpetrador del delito, pidiendo que se ejecutasen en él las más graves penas legalmente establecidas «contra los que urtan colmenares en los campos yermos y despoblados». En el escrito de su defensa no se emplea el verbo hurtar, sino que se opta por el de tomar-tomado una colmena-, además de alegar las excepciones de no haber sido puesta la acusación en tiempo y forma, que la querella contenía una relación falsa de los hechos y que los testigos de la sumaria no formaban prueba alguna concluyente. Por supuesto, se manifestó que el acusado era persona honrada de quien no se podía presumir hubiera cometido este hurto. Ante las dudas, en un hecho que en teoría era considerado delito grave, y la falta de pruebas concluyentes el juez, de acuerdo con los criterios de la época y quizá por la reiteración de tales sustracciones en la comarca, en junio de aquel año dictó sentencia de tormento contra el acusado para averiguar la verdad. Esta decisión fue apelada, tachando a los testigos y negando que el menor acusado hubiera tomado la colmena, por lo cual en modo alguno podía ser condenado en pena corporal, «por aver sido en cosa de tan poco valor que ajusta y común estimación en aquella tierra no valía más de seis reales», entre otros argumentos. Repárese en la diferencia de valor con el supuesto detallado con anterioridad, que reducido a reales quintuplica la tasación que hacía aquí la defensa. Por el contrario, el fiscal Gregorio Tovar solicitaba la conformidad de la sentencia de tormento, pues mediante su aplicación se podría conocer si otras personas le habían dado consejo, favor o ayuda. La sentencia de los alcaldes del crimen de Valladolid anuló la dictada por la justicia de Arenas, pero condenaron al acusado en destierro de la Chancillería y de la mencionada villa por dos años cumplidos, la mitad precisos y la otra mitad a voluntad de la sala, el 30 de julio de 1591, quizá con una finalidad más preventiva que punitiva. El arrepentimiento y la devolución de lo hurtado condujeron, sin duda, a la imposición de una pena leve en comparación con la prevista en la legislación, pues si bien hay destierro, no se impusieron los azotes de Nueva Recopilación $8,13,3$. Repárese, asimismo, que quien conoce y resuelve esta causa es el juez ordinario y no uno de la Hermandad.

En otra causa criminal, bajo la querella de hurto y daños provocados en una posada de colmenas, se encubría la reclamación de su posesión y ciertas diferencias familiares. Así sucedió en Talavera de la Reina en 1587 entre un padre y su hijo. En la acusación se describía la situación y elementos de la posada de colmenas -corrales tapiados, cerrados con sus puertas ${ }^{40}-$, la castración de la colmena sin voluntad ni con-

\footnotetext{
${ }^{40}$ Como decía José Antonio Sampil, «un colmenar cerrado y cubierto es ventajoso para las abejas y para el dueño, que tiene seguras las colmenas de ladrones, zorros y otros animales que las trastornan para devorar la miel que juntaron», en Nuevo plan de colmenas, o Tratado histórico-natural, físico económico de las abejas, Madrid, 1798, p. 94.
} 
sentimiento de su dueño, la atribución al padre de «muy grave delito» y se estimaba el valor de lo que se había llevado en la cantidad nada desdeñable de cien ducados, además del daño y perjuicio causado ${ }^{41}$. Desde luego la reclamación económica era desmedida en comparación con otros lugares. El proceso en realidad versaba sobre materia civil, pues se trataba de delimitar a quién pertenecían las colmenas, si al padre por haberlo heredado de una hija fallecida sin hijos a quien previamente se la había dado en dote, o al hijo que la habría recibido por donación de su padre. Tanto el alcalde mayor como el tribunal decidieron que mientras viviera el padre gozaría y disfrutaría del colmenar, y tras su óbito pasaría al hijo.

Los problemas para las partes en litigio se multiplicaban cuando los robos versaban sobre enjambres o cortijos de abejas silvestres, no colocados en colmenas. La propiedad de los mismos se verificaba mediante una marca y el conocimiento público del vecindario. Lo cual no evitaba los litigios, como sucedió en una villa de Galicia en 1627, al no respetar unos vecinos tales signos de propiedad y negar la publicidad que alegaban los querellantes. La sustracción no solo se había producido en yermo, sino de noche, aprovechando sin duda la menor actividad de las abejas, su consiguiente peligro y evitar ser vistos por otros vecinos ${ }^{42}$. Controversia agudizada porque la parte contraria también afirmaba que el enjambre le pertenecía, pues lo habían descubierto y marcado como propio, acompañando diferentes pruebas a su favor ${ }^{43}$. Resulta obvio que los acusados lo entendían de otra manera, pues la propiedad de estos enjambres ubicados en los montes era discutible y discutida, ya que no solo lo habían

\footnotetext{
${ }^{41} \mathrm{ARChV}$, Ejecutorias, 1.648/9. El querellante «ynplorava les condenase a que le diesen y pagasen el valor cien cargas de miel e cera que de las dichas colmenas e castro dellas le avían sacado e llevado que estimava en cien ducados que balían a su justa e común estimación con el daño e perjuicio que se avía echo en las dichas colmenas por las aver castrado excesivamente...». Tanto por él como por la otra parte se detalló todo el tracto civil de las colmenas.

${ }^{42}$ Se inició por querella, admitida el 7 de junio de 1627: «hes ansi que puede aber mes y medio quel dicho my ijo alló una colmena hen un roble en el monte que dyzen el monte de Barreyro térmyno de Folgueiras a donde yo y el dicho my yjo theníamos señalado y demandado por delante todos los beçinos del dicho lugar de Folgueiras... del dicho tiempo referido acá la reparábamos y granxeábamos como cosa nuestra propia y hespuéstola como ba referido con bysta y sabiduría de los beçinos y de la república y el dicho Alonso Méndez y su yjo se fueron al dicho roble el juebes de noche para amanescer... derrocaron hel dicho roble y del llebaron la dicha colmena, myel y cera... y ansí aber fecho an cometido, y por ser de noche delito y encurrido en grabes penas cibiles y cremynales». Archivo del Reino de Galicia (=ARG), Particulares, leg. 4.021/33, María Fernández de Pena Amil y Pedro Núñez de Pena Amil con Domingo Fernández y Pedro Méndez, «sobre un enjanbre que se diçe les llebaron de un roble que tenían aseñalado».

${ }^{43}$ Se recibió la correspondiente información y las partes alegaron. La querellante reiteró que «me llebaron y urtaron» la colmena, pedía que se declarara a los acusados como «echores y perpetradores del dicho crimen y delito», defendía que había probado la posesión de dicho enjambre y que era suyo propio, «por que por derecho es porque las dichas abexas son de las personas que las allan y recoxen». En uno de los testimonios se afirma que «donde ai probança no es de momento la presunción, y que yban de noche a coxer las avexas, de noche que de día no las podían coxer todas porque bien cosa notoria es que de día se coxen y no de noche y con lunbre». Ibídem.
} 
señalado sino que también habían dado publicidad a su ocupación y habían seguido las costumbres del lugar sobre el modo de hacerse con el enjambre ${ }^{44}$. La sentencia del inferior, «cerca del dicho enxambre de abexas de que se trata en quanto a la instançia deste juicio», decretó la absolución de los acusados, aunque el juez «por causas que me mueben» les condenó en costas. El motivo quizás se encuentre en los indicios para proceder contra ellos, pero también las dudas acerca de la fecha en que cada parte marcó el enjambre. Esta sanción pecuniaria motivó que los querellados acudiesen en apelación ante los alcaldes mayores del reino, cuya resolución final nos es desconocida ${ }^{45}$. Creo que el valor, no solo económico, de la producción apícola para una familia, más que la cuantía de las costas, está detrás del recurso. A lo que cabe añadir que la aceptación del pago de las costas suponía reconocer implícitamente que la parte querellante era la propietaria del enjambre.

Para entender el caso anterior puede servirnos de referencia lo afirmado por Torres Villarroel en su conocida obra sobre apicultura:

«Mientras permanecen en esta costumbre -de regresar a la colmena-, y no pierden (como dicen los juristas) el ánimo de bolver a sus dueños, se conservan estos en su posesión; y el que en tales casos los detiene, o toma, comete crimen de hurto, y queda ligado con las penas impuestas a los ladrones... Atendiendo a esta doctrina generalmente recibida de todos los legistas, es cierto, que mientras las avejas se mantienen en su libertad, de suerte que no han sido cerradas por persona alguna en colmena, o vaso, se entiende, que no tienen dueño, y se hacen por derecho natural del primero que las ocupa, y coloca en su colmena o vaso... y mientras permanecen en ella, sin perder la costumbre de salir al campo y volverse desde él a su colmenar y vaso, a ninguno le es lícito cogerlas, ni buscar medios para atraerlas ni sacarlas de la casa en que su legítimo dueño las colocó; y el que lo executa comete hurto, y debe ser castigado como ladrón... quando el dueño

\footnotetext{
${ }^{44}$ Los acusados adujeron que el juez «allará que las partes contrarias no an provado cosa alguna que nos dañe y que nosotros emos probado bien y cumplidamente nuestras defensiones y lo necesario para ser dados por libres y condenados en costas los contrarios y en las penas de la calunia... y en la tercera pregunta provamos plenamente que en quatro de junio emos allado el exanbre sobre que es este pleito en el monte de Barreiro en un roble y el mesmo día por la tarde públicamente lo emos recoxido llamando personas que nos ayudasen a lo recoxer; $y$ en quarta pregunta emos probado que sienpre los que mudan abexas de un trobo a otro las mudan al anocheçer o amaneçer por los enconbenientes que se siguen... y en la quinta que es costunbre del concexo quando salen enxanbres tarde como el que se trata los ponen en puestos más altos para que goçen de la flor de la montaña... lo otro, la parte contraria no a probado cosa en contrario ni en toda su ynformaçión se allará testigo que diga que le avisto allar ni señalar la dicha colmena en el roble ni aun quien diga que bio señal en él si no a sido Francisco y Pedro que el uno es de edad de treçe años y el otro de diez y seis y quando no [pu]dieran las tachas que tengo probadas, no tienen edad para testificar», en ibidem.

${ }^{45}$ El procurador de los acusados se presentó «en grado de apelación, nulidad y agrabio de cierta sentencia y determinación contra mis partes dada por el merino de la Puebla de Nabia, y en fabor de María Fernández contra mi parte por decir le abían hurtado una colmena y sin resultar culpa contra ellos ni aber ynformación bastante les mandó prender y dio sentencia en la causa, por la qual debiendo absolbelle y dar por libre ni lo a echo, antes por ella condeno a mi parte en las costas del proceso y otras cosas de la qual y más echo e proçedido y que yciere e procediere aquí ante VSa. apelo», en idem.
} 
lleva su enxambre fugitivo a la vista, si alguno con industria, o fuerza procura apartarlo de que lo haga, o hace otra diligencia para que se le pierda, con ánimo de aprovecharse de él, comete hurto, e incurre en sus penas ${ }^{46}$.

Entre las sentencias de la Audiencia de Galicia correspondientes al siglo XVII, consta una referida a la sustracción de colmenas -en plural- que fue castigada con la pena más grave de cuantas causas he consultado, pues el destino al remo impuesto por el juez inferior y la pena pecuniaria se aproximan a la severidad de las penas recopiladas sobre estos hechos. Aunque no conozcamos todos los pormenores, creo que se valoró más el hecho y el valor de lo hurtado, que la reiteración de estos hurtos en tierras gallegas ${ }^{47}$. Asimismo, el destino a galeras fijado por la Audiencia, en cuanto no es excesivo, parece considerarlo como un hurto simple.

Uno de los principales problemas para la prueba era conseguir el cuerpo del delito cuando se trataba del hurto de miel y cera. No sucedió así en tierras de la Ribera Alta alavesa en 1706, porque en el reconocimiento de la casa del acusado, al abrir un arcón que estaba en la cocina «en un rincón de este allaron un pedazo de panal de miel y zera sin deshacer y otros seis o siete pedazos detrás de dicho arcón, y otros muchos en un rincón de dicha cozina entre un montón de zeniza», incluso en un casco de olla otros dos pedazos de panal, además de panales sin deshacer, «y porque con lo referido se ajusta y prueba en bastante forma el cuerpo de delito de averme hurtado los panales de miel y zera de dichas tres colmenas, dejándolas maltradas y sin probecho, escalando para este efecto la cerca de dicha guerta y que dichos acusados fueron los agresores». El dueño de las colmenas, cura de Hereña, pedía la imposición de las penas «correspondientes a dicho delito que es de la mayor gravedad», calculando la pérdida en doscientos reales ${ }^{48}$, que es un cifra bastante elevada para lo visto más atrás. Además insistió, tras la declaración de los testigos, en la imposición a los reos de «las seberas y graves penas dispuestas por Derecho y leyes destos Reynos correspondientes a la gravedad y qualidad del delito», razonando esta petición en que el delito «es de suma gravedad así por su calidad como por las zircunstancias de que se biste y en particular la de averse ejecutado con escalamiento del zierre de mi guerta y en vienes que son de eclesiástico. Y porque a proporción de la referida gravedad y zircunstancias se

\footnotetext{
${ }^{46}$ Arte nuevo, pp. 348-352. Aclarando que «dícese y se entiende, que semejantes animales pierden el ánimo de bolver, y adquieren su libertad, quando faltan a aquella costumbre, que tenían en la salida, y regreso, o buelta; lo qual se ha de entender quando ellos la dexan por sí mismos, sin ser detenidos, o violentados; porque si alguno les impiden que buelvan, entonces permanecen de su primer dueño; y el que los aprisiona, o detiene, comete robo, y queda sujeto de sus penas».

${ }^{47}$ ARG, Sentencias, leg. 28537, sentencia de revista de 7 de noviembre de 1681, el Fiscal de S.M. con Juan Lorenzo, que confirmó la de instancia y la de vista que habían condenado al acusado en seis años de galeras al remo y sin sueldo, pero rebajando su duración a cuatro años y en diez mil maravedíes para la cámara de Su Majestad y gastos de Justicia por mitad. En ARG, Libros de la Escribanía de Gómez, Libro 60, Letra Fiscal, f. 292v., el Fiscal de S.M. «con Juan Lorenzo sobre robo de colmenas».

${ }^{48}$ Archivo Histórico Provincial de Álava, Justicia, 14.736.
} 
deven inponer y agravar a dichos reos las penas para su enmienda y ejemplo a otros y que queden condignamente castigados». Adviértase que estas calificaciones no se refieren específicamente al hurto de colmenas, o más bien de panales, sino que parecen dirigidas hacia un hurto genérico con las circunstancias que cita. El motivo puede encontrarse en que sería más fácil acudir a esta solución por la dificultad de encajarlo la legislación recopilada.

Uno de los acusados, además de alegar ser persona honrada e hidalgo, sostenía que los pedazos encontrados eran del tamaño de una nuez y haberlos recibido de otros acusados, por lo cual sostenía que si por hallarse dichos pocos pedazos de miel en su casa «fuese causa para poderse proceder, apenas se encontrará en un pueblo persona que se le imputase semejante delito porque todos los más regularmente tienen en sus casas un poco de miel». También negaba que se hubiese probado que estaban descorchados los tres vasos de miel y cera, «como era necesario constase por inspección ocular para que hubiese lugar al procedimiento», además de que el pastor de otro de los acusados fue inducido por su amo a descorchar los citados vasos. Otro encausado, padre del principal acusado, defendía su absoluta inocencia, al no existir contra él «ni el más remoto indizio, o presunción que le argüía del delito imputado», pues aunque se le quisiera indiciar por haberse descubierto en sus casas los mentados pedazos de panal, sus habitaciones y las de su hijo se encontraban separadas, habiéndose hallado en la cocina de éste los restos de miel y cera. La defensa del principal acusado pedía su absolución, o al menos la soltura bajo fianza, y el perpetuo silencio en la causa con la condena en costas del querellante. Su argumento principal incidía en que:

«debiendo de constar según lo resuelto por Derecho ante todas las cosas y en su ingreso del cuerpo del delito que se dijo ejecutado, e imputado a mi parte por la audiencia del echo y bista de ojos de dichas colmenas, se omitió esta diligencia tan esencial y no se pidió por dicho querellante, siendo el fundamento principalísimo de su intención... y porque es tan precisa la existencia del cuerpo del delito para el procedimiento criminal que aunque un hombre confiese voluntariamente aver dado la muerte violenta a otro no constando el cadáver no se puede proceder a la prisión y castigo del que confesó la muerte. Y porque en esta causa no se justifica por ningún medio el cuerpo del delito imputado a mi parte ni el daño de dichas colmenas».

Además de lo expresado como argumento esencial añadía, entre otras razones, las tachas de parentesco de los testigos y las dudas sobre sus deposiciones ${ }^{49}$; así como la debilidad de las presunciones, «pues en duda se debe descluir todo delito». Como es habitual, en la defensa del principal encausado se decía que era persona honrada y

\footnotetext{
${ }^{49}$ En un ladillo de los autos figura la siguiente nota: «Nótese la cautela con que declara este testigo su parentesco con el causante siendo sobrino carnal como antecedentemente lo tengo alegado y anotado y pareze de la cláusula de instituzión de heredero». El testigo deponía que «es pariente dentro de el quarto grado del dicho D. Juan Bautista de Villoria, no por eso declara de dezir verdad de lo que supiere».
} 
notorio hijodalgo de sangre, del mismo modo a como habían alegado los restantes. Trataba de eximirse sosteniendo que la procedencia de los mentados pedazos estaba en las colmenas de su padre, las que había descorchado y maltratado él sin su conocimiento tres o cuatro días antes del hurto hecho en las colmenas del clérigo.

En el ínterin el querellante murió, aunque su sobrino como heredero prosiguió el proceso. Adujo que en el registro «se alló y averiguó con claridad que ninguna de las referidas colmenas de dichos reos estava tocada ni rejistrada, y que de ellas no se avía sacado miel ni zera alguna de mucho tiempo aquella parte, de que se bino en claro y seguro conocimiento que no podía ser de dichas colmenas la que se avía allado en las casas de los susodichos», además de apoyarse en las deposiciones testificales. Asimismo esta parte alegaba que «siendo como es dicho delito de los que el Derecho estima de dificultosa probanza por el paraje y hora en que se executó, bastando en este caso solo los indicios, y mucha menos prueba, que la que se a echo de mi parte y se ajusta del proceso», resultaba que los acusados debían ser tenidos por autores del hurto.

La sentencia asesorada del alcalde mayor de la Ribera, de 18 de diciembre de 1707, en esta causa criminal «y demanda de daños», condenó a dos acusados en mil maravedíes, y a la mujer del principal encausado en cuatrocientos, aplicados por mitad a la cámara del conde de Orgaz y señor de la tierra de la Ribera y a gastos de justicia; a los dos primeros mancomunadamente en las costas de su prisión y carcelería, personales, procesales, asesorías y mensajerías, además de noventa reales «en los quales por justas consideraciones que resultan destos dicho autos modero y regulo los daños pretendidos y demandados por el dicho demandante por razón de los menoscabos causados en las abejas y miel y abejales descorchados». Hay que reparar en la considerable disminución de los daños por debajo de la mitad de lo solicitado, aunque continúa siendo una cantidad elevada si la comparamos con otros procesos anteriores, pues no solo se trataba del hurto de los panales, sino que dejaron las colmenas «maltratadas y sin provecho».

Encontramos problemas similares de prueba en otro hurto de colmenas sucedido en Galicia en el reinado de Felipe V, porque se negaba la existencia del cuerpo del delito $^{50}$. El querellante acusó a dos individuos de haber entrado, una noche de junio de 1712 , en su colmenar y escarcharle más de doscientas colmenas, matando a las abejas y llevándose la cera y la miel de ellas, por lo cual sostuvo que habían cometido «grave y atroz delicto». Los acusados manifestaron que había presentado la querella por ser rico y poderoso, además de pariente de un comisario de la Santa Cruzada. Su defensa incluyó comentarios al margen de la sumaria información y en las deposiciones de los testigos resaltando sus tachas: criado, de oídas, etc. En el escrito pidiendo la libertad de los acusados, el defensor alega que eran hijos de personas honradas, buenos cristianos, que vivían «sin hurtar ni llevar lo ajeno», valiéndose de sí y trabajando su ha-

\footnotetext{
${ }^{50}$ ARG, Particulares, leg. 5.790/18, por robo de colmenas a Pedro Taboada.
} 
cienda. Pero sobre todo que no había testigo de vista que depusiera que los acusados robaran en el colmenar, ni les hubieran visto salir de él; y que «por todos los autos no consta del cuerpo del delito, esto es que se fuese al dicho sitio de Maceyras y por donde dicen se hallaba el colmenar que se hallase roto, chancillado, destruido y robado que por su estado se pusiese por fe y deligencia, y es la piedra fundamental para el intento de la parte contraria». Tampoco se reconoció ni averiguó que en sus casas hubiese miel, cera ni instrumentos para castrar las colmenas, «ni fuesen allados en ferias, mercados, partes públicas ni secretas bendiendo zera ni miel alguna». A la vista de lo cual acusaba al querellante de formar liga con los testigos. En un escrito posterior, manifestó que la parte acusadora tenía mucho menos número de colmenas, «y que no an visto ninguna colmena destruida», ni se había demostrado que alguna estuviera castrada, ni tampoco se les halló parte de cera o miel en sus casas.

El querellante insistió en que estaban acostumbrados a llevar y hurtar lo ajeno, como habían hecho con sus colmenas. Se defendía que en este caso «se prueba por indicios y conjeturas porque los tales delitos son aborrecibles a bista de gentes, como son de noche y a desora y a tiempo que demás descansan del trabajo que hacen por el día», mientras los ladrones aprovechaban esas horas para perpetrarlos. En el escrito final, esta parte pedía la satisfacción de las colmenas que le descorcharon «a tasación de personas que entiendan la facultad de dichas colmenas y su producto»; al tiempo que reiteraba que estaba ajustado el cuerpo del delito mediante testigos.

Los reos fueron condenados en instancia a seis años de destierro del reino y seis mil maravedíes. Además, al querellante «quanto al interés civil sobre el colmenar, le reservo su derecho a salvo para que siga como viere le convenga». Uno de los acusados consintió la sentencia para que no se alargara más el proceso y por falta de medios, mientras que el otro apeló. Ese reconocimiento sirvió al fiscal para pedir la agravación de la pena y también para apelar ${ }^{51}$. Los alcaldes mayores de Galicia confirmaron el fallo anterior, pero moderaron la condena tan solo en cuanto a la exclusión territorial ${ }^{52}$.

Aunque en algunos procesos no se alega, resulta manifiesta la importancia que se dio en esta época a la miel y a la cera para la subsistencia de las familias. No puede,

\footnotetext{
${ }^{51}$ El fiscal de la Audiencia señalaba que los hurtos «se allan claramente justificados. El Real Tribunal se a de servir suplir la sentencia dada por el inferior a las penas en que an inqurrido y establezidas por Derecho, atendiendo a que además de lo que consta de una y otras provanzas se califica más bien del consentimiento echo de los sobredichos de dicha sentencia sin embargo de aberse apelado de ella a la cual se arrima y a mayor abundamiento la aze de nuevo». En la apelación de Touceiro se insiste en que falta el cuerpo del delito y no hubo reconocimiento, «siendo esta diligencia el primer paso en semejantes causas»».

${ }^{52}$ ARG, Sentencias, leg. 28.545, sentencia de vista de 9 de junio de 1716, el Fiscal de S.M. con Ignacio Touceiro y Manuel Rodríguez, en rebeldía, por la que se confirmó la dictada, con parecer de asesor, por el juez de la jurisdicción de Deza el 27 de mayo de 1713, pero fijando que los seis años de destierro fuera del Reino quedaran en ocho leguas al contorno de dicha jurisdicción de Deza, donde eran domiciliarios, y de la ciudad de La Coruña.
} 
sin embargo, reducirse la autoría de estos hurtos a personas de escasos recursos, cuando no pobres de solemnidad. De hecho, no he encontrado en los autos consultados menciones expresas a una situación de necesidad como amparo para una rebaja punitiva $^{53}$.

Como he apuntado, el hurto de colmenas es un delito típico entre vecinos. De ahí que en ocasiones la acusación se dirija, con certeza o no, contra quienes la fama pública tiene por ladrones dentro de cada comunidad ${ }^{54}$. Ello obligaba a realizar los trámites procesales habituales, aunque los acusados negaran la perpetración de delito y no hubiera pruebas contundentes contra ellos ${ }^{55}$. En estos casos, el juez y las partes son convecinos, por lo que puede intuirse la existencia de otros conflictos vecinales en los que el primero se inclina por alguna de ellas ${ }^{56}$.

\footnotetext{
${ }^{53}$ En otros momentos y casos se alegaron, cfr. Mendoza, Delincuencia, p. 291, nota 43.

${ }^{54}$ ARG, Particulares, leg. 3.457/45, Antonio Fernández con Esteban Morado, María Gil, Pedro Morado y Silvestre Morado «sobre delitos». Se inició por auto de oficio de 26 de octubre de 1712 por el juez de San Pedro de Labrada, al conocer que «teniendo Antonio Fernández vezino de dicha feligresía de Aldixe dos colmenas en su alvariza pobladas de miel, zera y abexas que la noche del día veinte y cinco se fueron los referidos y se las mataron y llebaron miel y zera que tenía para su casa, dexando como dexaron los trovos en que estaban despoblados y echo otros más hurtos, por cuia razón y sean castigados conforme a dichos delitos y que sirva de ejenplo en la república, mandava y mandó hazer contra ellos y más que resultaren culpados este auto de oficio». En la información de testigos, el primero dio cuenta de sus apreciaciones sobre la cantidad de miel que tenían los querellados. Otro declaró que oyó aquella noche que «hurtaron a Antonio Fernández vezino de Aldixe dos colmenas pobladas de miel cera y avexas y que se echava la culpa a dos Morados, no save si lo fueron o no, mas de que le causa sospecha por oír antes de aora entre los naturales como dexa dicho que los referidos lleban lo ajeno y el abérseles allado tanta cantidad de miel...»; y un tercero «oió deçir por público que los referidos acusados son ladrones y usaron de lo ajeno contra la voluntad de sus dueños y dando más satisfazión a lo que le pregunta».

${ }^{55}$ El auto de prisión se ejecutó el 3 de noviembre de 1712, al tiempo que se reconocieron las vasijas de miel y se embargaron sus bienes. Les fue tomada confesión en la cárcel de dicha jurisdicción el 13 de noviembre. El hermano menor negó las preguntas por ser siniestras y ajenas a la verdad, pues por ser acomodados no tenían que usar de lo ajeno. El mayor también negó, ya que «jamás le a pasado por la ymajinazión bivir de lo ajeno». Se hizo el cargo, mandando que guardaran la carcelería en dicha cárcel.

${ }^{56}$ La defensa de Esteban Morado hizo agravio ante la Audiencia del juez de Castromayor, su teniente, merino y ministros, pues a pesar de que sus partes nunca habían usado de lo ajeno, se les hizo causa a petición de Antonio Fernández, herrero, «con el subpuesto de que le avía faltado dos colmenas y sin que constase la persona en caso que fuese çierto que se las ubiese echo de menos, con estrépito y arrojo dicho juez y su teniente, y escribano, pasaron a rejistrar la casa en que biven... obrando con notoria pasión, nulidad y agrabio en desdoro del crédito de mis partes porque siendo necesario dar contra dicha justicia querella criminal en forma y pido se le multe y castigue por el modo de proceder y le recuso de odiosa y sospechosa, para el conocimiento de dicha causa suplico a V.S. se sirva mandar que aviéndole por tal, dé la causa y raçón que ha tenido, y le conpelan... El conocemiento toca a VS por ser queja contra justicia y apela de lo por ella obrado». Se mandó despachar provisión de causa y razón el 5 noviembre de 1712, pero no consta sentencia del tribunal. Aunque desconozco el motivo, Esteban Morado, pobre de solemnidad y como tal mandado ayudar, fue condenado en 1717 por el alcalde mayor de Mondoñedo en vergüenza pública y dos años de galeras, pena rebajada por la Audiencia a cuatro años de destierro del reino, por sentencia de 22 de agosto de 1722, en ARG, Sentencias, leg. 28.489.
} 
Es frecuente descubrir cómo las acusaciones por hurtos de abejas y otros animales esconden diferentes problemas en los que las relaciones vecinales y parentales juegan un papel crucial. La justicia ordinaria ha de actuar de oficio tan pronto como le conste el robo de las colmenas, «para que semejante y atroz delito tenga el condigno castigo que merece ${ }^{57}$. Pero la inmediatez de la convivencia en que se encontraban todos los intervinientes desemboca en la queja de parcialidad por parte del acusado contra el juez, lo que permitía que el proceso fuera conocido por la Audiencia antes de la resolución en la instancia y posiblemente facilitara una solución extraprocesal, porque en realidad la querella por hurto oculta litigios de orden civil ${ }^{58}$. Este supuesto de parcialidad en causas incoadas por hurtos de colmenas parece reiterarse incluso cuando acusador y acusado son parientes ${ }^{59}$.

${ }^{57}$ ARG, Particulares, leg. 22.164/47, Pedro Domínguez y Pedro Pérez contra Pedro Núñez Noguerol. Se inició la causa por auto de oficio de 18 de noviembre de 1746 de la justicia de Muniferral, por habérsele dado noticia que ese día «se avian quitado y rovado una alvariza de avejas que thiene Pedro Peres y su suegro Pedro Domínguez vezinos del lugar de Jora feligresía de Santa María de Oya con cantidad de avejas miel y cera, y que se avían conducido a esta feligresía y casa donde vive Pedro Núñez y para que semejante y atroz delito tenga el condigno castigo que merece y a los que resultaren cónplices sirva de tal y a otros dejenplo mando acer este auto de oficio». Tras la información de testigos, se pasó a la casa de Núñez, quien huyó, descubriéndose un cortijo de avejas, y al entrar su mujer decía «vien savía a lo que venían, que ella tanvién tenia avejas, sin decírsele cosa alguna». Pedro Pérez presentó querella contra el acusado cinco días más tarde, alegando que encontrándose en la posesión de los bienes que Pedro Domínguez, su suegro, le entregó de dote a su mujer, le habían hurtado dos cortijos de abejas y hecho con anterioridad otros hurtos de cuadrúpedos. Se inserta también una querella de Domínguez, hombre de crecida edad, sordo y cargado de achaques, en la que se quejaba que su hija no le daba el cariño exigido, pues faltando a toda obligación natural había tenido acceso carnal con Núñez, quedó embarazada y sin su consentimiento se casó.

${ }^{58}$ El procurador de Pedro Núñez se quejó y agravió del juez del coto de Muniferral, escribano y demás culpados, diciendo había vivido honradamente sin usar de lo ajeno ni causar nota ni escándalo en la república, pero su suegro, Pedro Domínguez, «a fin de denigrarle su buen crédito y reputazión en que se alla, y exsimirse de darle la dote que le corresponde a su muger, discurrió con premeditado artifizio, y mala boluntad que profesa a hija e yerno, por estos averse casado contra su gusto», el acudir ante el juez imputándole ciertos hurtos, lo que era contrario a la verdad. El juez y el escribano actuaron contra él por el valimiento que tenía sobre ellos el suegro, lo que le incitó a huir y a presentarse ante los alcaldes mayores. El auto de 2 de diciembre de 1746 admitió la querella, se le dio la ciudad por cárcel y se ordenó recibir información de pobreza. No hay sentencia ni más diligencias de la Audiencia. Es posible que hubiera concordia.

${ }^{59}$ ARG, Particulares, leg. 20.829/12, Manuel Álvarez con Antonio Álvarez «sobre robo de colmenas». El primero era sobrino del segundo. Antonio Álvarez presentó su querella en agosto de 1757, en la que exponía que el acusado extrajo «una colmena de mi colmenar, y la llevó a un su cortiñeiro sito no Palferro en donde la he encontrado y reconocido. Y asimismo por otras veces me ha urtado otras dos colmenas sin themor de Dios, robando lo más que puede no solo a mi sino a quantos pueda, como es público y notorio, pública voz y fama en mi vecindad. Y aunque por alguno se a reconvenido de sus atroces delitos, y de su mal modo de vivir, siempre responde que sus quimeras las compone con dinero y esforzado en su caudal vive sin ley de Dios llevando lo ajeno contra la voluntad de su dueño». Cuando se sentía culpado se escapaba por su cercanía a Portugal. Según uno de los testigos, Antonio tenía un colmenar cerrado con varias colmenas, «y habiendo corrido la noticia de que le avían urtado una colmena y enxam- 
Admitiéndose la dificultad de su probanza por cometerse en lugares despoblados, la conveniencia de que se realizara una inspección bien ocular ${ }^{60}$, bien pericial ${ }^{61}$, junto con la concurrencia de otros elementos, entre ellos la posible confusión de unos enjambres con otros, el borrado de las marcas de propiedad o, simplemente, la extracción de la cera y de la miel sin quebrantar la colmena o vaso, conducen a unos procesos en los que las dudas planteadas al juzgador debieron moverle a la imposición de absoluciones o penas muy leves por la inexistencia de pruebas tan claras como la luz del día.

Como complemento de lo anterior, la punición efectiva de los reos acusados de robar colmenas debió ser más severa en la práctica que el hurto de cera y miel, aunque es difícil determinar hasta qué punto por la falta de series o de grupos de causas dentro de un período cronológico delimitado y pertenecientes a un mismo territorio. No obstante, paulatinamente se van inclinando los juzgadores por la reparación económica del daño y, a lo sumo, un leve destierro que nada tiene que ver con el castigo recopilado previsto en las Ordenanzas de la Hermandad. Quizá por ello es habitual encontrar menciones por parte de la acusación al valor de lo hurtado o a los daños producidos en las colmenas. Tasaciones que son diferentes, como hemos visto, según el lugar y que no parecen estar relacionadas con las cifras fijadas en dichas Ordenanzas.

Es imposible determinar cuántos procesos sobre hurtos de colmenas o miel y cera quedaron resueltos en la instancia inferior, probablemente muchos, pero la circuns-

bre nuevo con su cortizo, bien conocido por ser de corcho... habiendo pasado el testigo al sitio de Palferro término deste lugar donde Manuel Álvarez querellado tiene un cortiñeiro plantado de viña, y habiendo reparado, vio que en él había una colmena, la que reconoció por estar puesta allí de poco tiempo, ser enxambre nuevo y un cortizo de corcho», el mismo que había faltado, «fuera de que dicho querellado no tiene colmenas algunas y es persona acostumbrada a ser ratonero». Manuel era para unos «hombre acomodado en línea de labrador», para otro revoltoso en la república. Para el acusado la información estaba dada por criados, parientes y paniaguados de la otra parte. Manuel apeló del auto de prisión y se presentó ante los alcaldes mayores, quienes le dieron la ciudad por cárcel y le permitieron retirarse a su domicilio sin ser molestado por la justicia. La Audiencia impuso las costas al apelante. Al final se convirtió en un proceso contra el juez por procedimientos.

${ }^{60}$ Miguel Cayetano Sanz, Modo y forma de instruir y sustanciar, Madrid, 1796, p. 73 (caso 11): «Robo de colmenas. Cuando se hubiese descorchado algún colmenar, pasará a él el juez con el escribano y testigos, y habiendo fracturas de paredes o puertas, se harán las diligencias que muchas veces van ya repetidas, y demás de esto se nombrarán, dos peritos que reconozcan y declaren el estado que tienen las colmenas, y cuanto sea conducente, así para justificar el cuerpo de este delito, como el daño que han padecido. Se tratará de averiguar cuántas colmenas había antes del descorcho, en qué estado se hallaban, y para ello se examinará al robado, y a los que este dijese lo podían deponer». Con las mismas palabras Eugenio de Tapia, Febrero novísimo, o Librería de jueces, abogados y escribanos, Valencia, 1829, tomo VII, p. 295.

${ }^{61}$ En este sentido, se advertía que «si hubiesen prendido al reo, y le hubiesen hallado algún grano, buscarán dos labradores que digan y cotejen aquel fruto, de lo cual dará fe el escribano... Y cuanto va dicho del robo de los granos se entenderá de los vinos, colmenas, etc, teniendo el juez presente el depósito y declaraciones», según Vicente Vizcaíno Pérez, Código y práctica criminal, arreglado a las leyes de España, Madrid, 1797, tomo II, lib. III, p. 202. 
tancia de que algunas de ellas llegaran a conocimiento de los tribunales da idea de la importancia que se dio a lo hurtado, con independencia de que en diferentes juicios concurrieran otros aspectos, entre los que el principal es, sin duda, el castigo impuesto a los reos. Sin desdeñar que en otras causas, en las que las partes enfrentadas procesalmente por algún hurto de colmenas o por el producto de las abejas eran parientes, se buscara cualquier remedio extraprocesal para no continuar con el proceso.

A medida que se avanza en la consulta de la documentación judicial sobre sustracciones de colmenas se afianza la idea de que es esencialmente un hurto entre la vecindad, lejos de ser sus autores ladrones profesionales, aunque es posible que los hubiera. De nuevo lo comprobamos en otra causa por hurto, que más parece ser de miel que de colmenas, perpetrado a finales del siglo XVIII en tierras coruñesas ${ }^{62}$, en la que se entrecruzó una querella presentada por la parte acusada por injurias ${ }^{63}$. Estos problemas, que surgen en el seno de pequeñas comunidades rurales, también permitían que otros vecinos cercanos los avinieran y que, en principio, el conflicto concluyera mediante transacción ${ }^{64}$. La justicia inferior que conoció del asunto, afirmaba en el auto definitivo que «teniendo por una parte que el que se transige en causas de esta naturaleza, confiesa el delito», pero «que de hacerlo así y substanciarse por el orden y tramites que son indispensables, se siguiría infaliblemente la ruyna de marido y muger» $\mathrm{y}$ «no siendo de menos importancia las molestias y gravámenes que sufrirá todo el vecindario en la custodia y alimentos de los reos y sus hijos mientras la causa no se determina, por no haver cárcel segura, ni estar el carcelero sujeto a responsabilidad, con respecto y miramiento a todo esto, reflexionando los incombenientes, y usando de conmiseración», aceptó el convenio entre ambas partes, pero impuso por vía de corrección a los acusados quince días de cárcel, con cadena en el pie, bajo el

\footnotetext{
${ }^{62}$ ARG, Sala del Crimen, leg. 8, 34, Ignacio Paz contra Silvestre de Castelos y Catalina do Porto, sobre robo de colmenas. El 15 de enero de 1797 Paz observó que le faltaban algunas colmenas y que los acusados las habían retraído para su casa y, al acudir a registrar la de Castelos, su mujer tiró a un riachuelo una caldera de miel. Se reconoció la caldera en la que había una porción de miel y cera, y la zona del riachuelo, pero no pudieron hallar a Castelos.

${ }^{63}$ Silvestre Castelos se querelló contra Ignacio y José Paz, alegando que nunca había usado de lo ajeno, mientras que estos hermanos eran propensos a injuriar. Manifestaba que había salido de su casa un lunes y vuelto el jueves, por lo que no pudo ser el autor. Se quejó de la gente que entró en su casa y maltrató de palabra y obra a su mujer, sola con cinco criaturas, señalando que la mujer de Pedro Domínguez le había regalado unos panales. Pedía se castigase por injuria a los hermanos, afianzando hasta quinientos ducados, con satisfacción pública de palabra o por escrito, con prisión y embargo de bienes.

${ }^{64}$ El auto del juez de Muniferral, de 24 de febrero de 1797 ordenó, en vista de lo actuado, arrestar a Silvestre Castelos y Catalina do Porto, con prisiones seguras, embargo de bienes y toma de confesióne. Pero el 14 de marzo Ignacio Paz y Silvestre Castelos presentaron pedimento de transacción, porque «en este estado han mediado algunas personas prudentes que nos mobieron a tranquilarnos y en efecto amando la paz nos allamos compuestos y transigimos». Lo hicieron en la forma siguiente, Castelos por el importe principal de las tres colmenas y sus producciones, mientras Paz por los gastos: Castelos a Paz 280 reales, separándose Paz de alguna «repetencia», quedando a cuenta de aquel la satisfacción de los gastos de justicia. En cuya conformidad se apartaban de la causa.
} 
apercibimiento de presidio al marido y reclusión a la mujer en caso de reincidencia, que el primero debía cumplir inmediatamente y la segunda tras el parto ${ }^{65}$. Adviértase que transigir era confirmar la autoría - como sucedía con la fuga-, pero los inconvenientes que de ello se derivarían para acusados y vecinos eran harto perjudiciales; $y$, además, se aprecia la aplicación de la cárcel como método de corrección, sin perjuicio de las graves penas con que se apercibía para el caso de repetición de estos delitos.

A pesar de la importancia que fue adquiriendo el azúcar de caña en sustitución de la miel, en las zonas rurales los colmenares continuaron siendo objetivo de los ladrones. En este sentido, a finales del siglo XVIII en Extremadura se siguen lamentando los «frecuentes hurtos de cera y colmenares». Carmona Gutiérrez destaca que en algunas de las poblaciones del partido de Coria la merma en la cría de abejas se debía a «los reiterados hurtos que han experimentado y experimenta a cada paso», acusándose a los vecinos de Ceclavín y Zarza «que las descorchan y matan para aprovecharse de la zera que en sí contienen». Para su remedio se proponía construir «un refugio general de todas las colmenas que ay en cada pueblo», formar un libro maestro con las que tuviera cada vecino y obligar a declarar las ventas ${ }^{66}$.

Por otra parte y a pesar de que, como se señaló más arriba, el hurto de colmenas no podía comprenderse en el abigeato según la regulación de Partidas, existió una corriente que pretendió incluirlos dentro de los robos genéricos de animales. Pedro y Manuel Antonio Cervantes señalaban, tras afirmar que los abigeos más que cazadores eran «robadores de la hazienda agena» siguiendo a Damhouder, que entre ellos había que incluir «a los que hurtan conejos, ánades, gansos, pabos, gallinas, colmenas, y otras cosas semejantes, y dize le deben castigar arbitrariamente, según las circunstancias, y calidad del derecho y la persona $\rangle^{67}$. Sin duda que el arbitrio judicial jugó un papel esencial en la atemperación de las penas y en favor de unos castigos proporcionales para los hurtos y daños a colmenas.

En la misma línea, a comienzos del siglo XIX el último criminalista español del Antiguo Régimen afirmaba como práctica de todos los tribunales «fulminarse causa

\footnotetext{
${ }^{65}$ El auto definitivo del juez, de 28 de marzo de 1797, vistas las diligencias y convenio, señalaba que «devía de haber y ha por apartados del siguimiento de esta causa al querellante y querellados en conformidad del pedimento combencional que tienen presentado, pagando estos a aquél los duscientos y ochenta reales a que se obligaron, y los gastos y costas ocasionadas y que se ocasionaren». Se consultó a la Sala del Crimen, que por auto de 29 de julio de 1797 dispuso que la justicia de Muniferral, consultando el auto definitivo lo ejecute, remita los autos originales, haga saber el de providencia a las partes y les otorgue las apelaciones. A lo que parece no hubo lugar.

${ }^{66}$ Jéssica Carmona Gutiérrez, «El delito en el campo: daños, hurtos, fuegos y cortes en el ámbito rural extremeño a finales del Antiguo Régimen», en Clio \& Crimen, 11, 2014, pp. 79-100, a partir del Interrogatorio de la Real Audiencia de Extremadura de 1791. Así, menciona, que aparecen 113 referencias a robos de colmenas, dándose la mayor preocupación en las poblaciones del partido de Cáceres, y en el de Mérida en el que menos.

${ }^{67}$ Recopilación de las Reales Ordenanzas y Cédulas de los Bosques Reales del Pardo, Aranjuez, Escorial, Balsaín y otros, Madrid, 1687, p. 88. El autor al que se remiten es Joost van Damhouder y a su obra Praxis rerum criminalium.
} 
por escrito y con rígida formalidad en los hurtos de esta especie -abigeatos-, que valen poco (como el de una sola res, o una sola colmena) e imponer penas de destierro a los transgresores; quando por otros hurtos simples de igual importancia está prohibido fulminarse ${ }^{68}$. Así pues, sin entrar en la vulgarización del concepto de abigeato, se equiparaba el hurto de una cabeza de ganado y el de una colmena, para evitar resolver estos hechos por la vía procesal ordinaria y acudir a un procedimiento más sencillo. Lo cual permite sostener la pérdida de importancia económica y judicial de los hurtos de colmenas - que algunos autores, no todos, dejan de considerar atroces$\mathrm{y}$, en consecuencia, de su punición, salvo que la cantidad, y por tanto su valor, fuera importante.

La dificultad de valoración o su equiparación a hurtos de animales se resolvió legalmente acudiendo a la cantidad. El Código penal de 1822, en su art. 747 determinó que: «El que hurte una caballería, o un buey, o una vaca, o ganado menor de cualquiera especie, que no pase de cuatro cabezas, o colmenar que no pase de cuatro colmenas, aunque su valor no llegue a los seis duros, sufrirá la pena de uno a tres años de obras públicas; y si el hurto fuere de mayor número, se impondrá al reo un año más por cada caballería o cabeza de ganado mayor, o por cada cuatro del menor, o por cada cuatro colmenas $\rangle^{69}$.

La legislación penal posterior, incluidos los proyectos de Código criminal absolutistas, omitió cualquier mención específica a los hurtos de colmenas y silenció la equiparación con los hurtos de animales. El Código penal de 1848 prescindió de cualquier referencia al hurto de colmenas, por lo que habría que estar a su valoración de acuerdo con los arts. 426 y 427 , con independencia de los daños que se produjeran y fueran punibles, o que la sustracción tuviera la consideración de falta.

Esta teórica laguna legal provocó curiosas dudas. Resulta interesante la cuestión planteada por Antonio Resino sobre las disposiciones legales a las que había que recurrir en 1861 para otorgar la protección y defensa invocadas por los propietarios de posadas de colmenas y resolver las controversias suscitadas, lamentando el silencio existente sobre el número de colmenas que habrían de constituir una posada. A pesar de la vigencia del Código penal rebusca en la legislación alfonsina, manifestando que la falta de mención en ley a los hurtadores de colmenas y el silencio sobre un cierto número de ellas, impide encajarla en el abigeato ${ }^{70}$, con independencia de la gravedad de las

\footnotetext{
${ }^{68}$ Senén Vilanova y Mañés, Materia criminal forense: o tratado universal teórico y práctico de los delitos y delincuentes en género y especie: para la segura y conforme expedición de las causas de esta naturaleza, 1807, tomo III, cap. XVI, p. 148,

${ }^{69}$ Diarios de sesiones de las Cortes, sesión de 12 de febrero de 1822.

${ }^{70}$ Según Resino: «Examinando la ley 19, tít. 14 de la Partida 7, alusiva al delito conocido con el nombre de abigeato, he visto que nada se dice respecto al número de colmenas o de enjambres que han de hurtarse para calificarse este esceso como tal delito; cuya noticia nos daría alguna luz para aventurarnos a indicar el número de colmenas que debían dotar cada posada o colmenar al indicado propósito», en El Faro Nacional, 17 de septiembre de 1861, pp. 335-337.
} 
penas impuestas a quienes sustrajeran colmenas. También alegará como protección de los colmeneros y rudeza contra los ladrones la gravedad de las penas que recogía la legislación medieval y moderna, pues «cuanto más distantes estén de sus colmenares y más ocupados en otras faenas, más eficaz protección se les debe dispensar». Máxime cuando el colmenar estuviera delimitado y marcado con la señal del propietario.

Desde otra perspectiva, el Decreto de caza y pesca de 3 de mayo de 1834 vino a alterar los criterios seculares acerca de la aprehensión de enjambres de abejas, puesto que los juristas interpretaron, a partir de lo dispuesto en su art. 7, de acuerdo con el cual la caza caída en tierra de propiedad particular o que hubiera entrado en ella después de herida, pertenece al dueño o arrendatario de la tierra y no al cazador, y que solo se podía cazar sin licencia de los dueños en las tierras abiertas de propiedad particular que no estuvieren labradas, «es claro y consiguiente que si un enjambre escapado de su colmenar se introduce en heredad ajena y el dueño del colmenar deja de perseguirle dándole por perdido o abandonado, no puede un tercero entrar en la heredad a cogerle, pues queda entonces a favor del dueño de esta; pero bien podrá entrar con dicho objeto si la heredad es abierta y no está labrada o está de rastrojo, sin que en tal caso tenga facultad el propietario de la heredad para impedirle el ejercicio de un derecho que la ley nueva le concede». El dueño de la heredad no podría negar al del enjambre la entrada en ella para cogerlo mientras fuere en su seguimiento, «porque el dueño de un abejar conserva siempre el dominio del enjambre hasta que le abandona por no querer o no poder cogerle» ${ }^{71}$. El art. 612 del Código civil resolvió la ocupación de los enjambres.

En el siglo XIX no se hará mención a la finalidad que durante la Edad Media y Moderna justificaba la persecución y la severidad de las penas impuestas contra los hurtadores de colmenas. Por razones conocidas se insistirá en el concepto de propiedad y en la utilidad de su aprovechamiento por los legítimos dueños:

«Los incendios y hurtos que se ejecutan en los colmenares están comprendidos por la ley en la clase de delitos atroces, y por eso el espíritu de ella establece castigos muy severos contra los malhechores de colmenas. Además de que se ataca directamente la propiedad con la perpetración de esta clase de delitos, cuyas circunstancias si bien se examinan son agravantes, y de una tendencia maliciosa y pensada, la sociedad recibe muchos daños en el deterioro de este ramo necesario de industria, destinado por la Providencia a subvenir a las necesidades del hombre. Muchos ignorantes pretenden persuadirse de que un robo de cien arrobas de miel es una golosina, y que el colmenero no tiene derecho a reclamar lo suyo, ni la sociedad a vindicarse. La justicia pide imperiosamente que se castiguen los ladrones de colmenas; y las leyes fundadas en esta virtud divina establecen.... $\gg^{72}$.

\footnotetext{
${ }^{71}$ Joaquín Escriche, Diccionario razonado de legislación y jurisprudencia, Madrid, 1838, tomo I, p. 23, voz abejas.

${ }^{72}$ Eusebio Ruiz de la Escalera, Practica fija de colmeneros, Madrid, 1835, pp. 99-105, hizo cálculos acerca del coste y producción de cien colmenas, lo que le servía para ponerlo en relación con R. 8,13,3.
} 
A expensas de lo que puedan aportar nuevos trabajos, el hurto de colmenas, abejas, miel o cera puede ser considerado como uno de los más antiguos y cuya protección específica se mantuvo hasta mediados del siglo XIX. Fue considerado un delito atroz ya que el propietario del colmenar no podía extender su vigilancia directa sobre él por hallarse, habitualmente, alejado del núcleo rural. Asimismo, en algunos de ellos concurre la nocturnidad o se verifican por colmeneros en los abejares de sus amos, e incluso se alude al escalamiento en la práctica forense. Su conocimiento en la instancia inferior permite observar unos procesos en los que el cuerpo del delito y la prueba testifical presentaron, en ocasiones, notables deficiencias. La punición legal fue paulatinamente adquiriendo por vía judicial mayor lenidad, no sobrepasando, con carácter general, unos leves destierros y la reparación económica del daño ocasionado. Para su determinación se valoró específicamente qué era lo hurtado: la colmena (conjunto) o la miel y cera (partes). También se consideró el daño provocado y la valoración que hacía la parte perjudicada. Una estimación que variaba considerablemente de unos lugares a otros. Hasta donde tenemos noticia, se trataba de un hurto eminentemente vecinal, a veces cometido entre parientes, y cuya autoría es a lo sumo individual o familiar. Todo lo contrario de lo que parece suceder hoy en día. 